\title{
Perbandingan Berat Hati Tikus Spraque Dawley yang Diberikan Diet Kurang Kalori, Cukup Kalori, dan Tinggi Kalori pada Masa Pertumbuhan
}

\author{
Jelita Inayah Sari*, Ahmad Aulia Jusuf**, Ening Krisnuhoni*** \\ *Program Studi Pendidikan Dokter, FKIK UIN Alauddin \\ **Departemen Histologi Fakultas Kedokteran Universitas Indonesia \\ ***Departemen Patologi Anatomi Fakultas Kedokteran Universitas Indonesia
}

\begin{abstract}
ABSTRAK
Perlemakan hati merupakan penyakit degeneratif yang dapat berkembang pada masa pertumbuhan. Perlemakan hati dapat terjadi pada dua kondisi yang sangat berbeda jauh secara patofisiologi yaitu kondisi kekurangan kalori dan kelebihan kalori. Penelitian ini bertujuan untuk membandingkan ukuran berat hati pada pemberian diet tinggi kalori, cukup kalori, dan rendah kalori pada tikus selama masa pertumbuhan. Sampel penelitian menggunakan 15 organ hati Spraque Dawley usia 6 minggu yang diberi asupan kalori berbeda selama 8 minggu. Penelitian ini terdiri atas 3 (tiga) kelompok yaitu kelompok kurang kalori (KK), kelompok cukup kalori (CK), dan kelompok tinggi kalori (TK). Parameter penelitian adalah pemeriksaan berat hati utuk menilai hepatomegaly. Hasil penelitian menunjukkan kelompok TK mengalami kenaikan berat hati $\pm 20 \%$ lebih besar dibandingkan dengan kelompok CK dan kelompok KK $(\mathrm{p}<0,05)$. Penelitian ini menyimpulkan bahwa diet tinggi kalori dapat menyebabkan terjadinya hepatomegaly.
\end{abstract}

Kata kunci : perlemakan hati, hepatomegaly, diet tinggi kalori

\section{PENDAHULUAN}

Malnutrisi masih menjadi masalah kesehatan anak di Indonesia dengan prevalensi gizi lebih $8 \%$, gizi kurang $13,8 \%$ dan gizi buruk 3,9\% (RISKESDA 2018). Malnutrisi didefinisikan sebagai terjadinya ketidakseimbangan antara asupan dan kebutuhan yang diperlukan oleh tubuh. Kekurangan kalori-protein adalah salah satu jenis malnutrisi yang banyak terjadi pada anak-anak karena kebutuhan nutrisi yang lebih besar dibandingkan pada orang dewasa. Kekurangan kalori-protein akan mengganggu proses pertumbuhan dan perkembangan. ${ }^{1-3}$

Status gizi pada masa kecil dapat berdampak pada kesehatan anak ketika dewasa. Faktor-faktor seperti gaya hidup, perbaikan ekonomi, perubahan pola diet, dan makanan tinggi kalori-lemak yang semakin mudah ditemukan akan mengarah pada perkembangan penyakit-penyakit degeneratif. Hal ini dapat terjadi pada berbagai kondisi, baik pada anak-anak yang masa kecilnya kekurangan kalori, normal, maupun obesitas. Salah satu penyakit degeneratif yang banyak dikaitkan dengan kondisi ini adalah perlemakan hati non alkohol (Non-Alcoholic Fatty Liver Disease, NAFLD). Penelitian membuktikan, NAFLD berkaitan dengan kondisi kekurangan kalori maupun diet tinggi lemak dan obesitas. Studi yang dilakukan oleh Tim van Zutphen dkk menunjukkan hubungan NAFLD dengan defisiensi protein. Berkurangnya jumlah 
karbohidrat dapat membawa konsekuensi timbulnya defisiensi protein. Hal ini dapat mengganggu pembentukan organel sel yang berperan pada proses metabolisme, seperti mitokondria dan peroksisom yang berperan pada metabolisme lemak. Gangguan ini akan mengakibatkan penurunan oksidasi asam lemak dan menyebabkan akumulasi lemak (triasilgliserol) di hati. ${ }^{4-7}$

NAFLD juga sering dikaitkan dengan diet tinggi lemak, obesitas, dan resistensi insulin yang akan mengarah pada gangguan lipolisis di perifer, sehingga uptake asam lemak ke hati meningkat. Ketidakseimbangan antara sintesis, absorbsi dan sekresi asam lemak akan menyebabkan akumulasi di hati membentuk NAFLD. NAFLD dapat memicu perubahan morfologi (bentuk) hati terutama hepatosit dan struktur di sekitarnya. Secara makroskopis, NAFLD biasanya disertai dengan hepatomegali.

Sampai saat ini, yang banyak diteliti adalah hubungan NAFLD dengan diet kurang kalori-protein saja atau hubungannya dengan diet tinggi lemak saja, belum ada penelitian yang membandingkan hubungan keduanya terhadap perubahan berat hati. Penelitian ini bertujuan untuk membandingkan berat hati pada tikus usia pertumbuhan yang berbeda intake kalorinya (kurang, cukup, dan lebih). 2,3,9,11-12

\section{BAHAN DAN METODE}

Penelitian ini dilaksanakan di Laboratorium Histologi Fakultas Kedokteran Universitas Indonesia pada tahun 2018. Subjek penelitian ini berupa 15 hati tikus jantan Spraque Dawley usia 6 minggu yang diberikan intake kalori berbeda selama 8 minggu. Peneliti sebelumnya telah melakukan intervensi diet pada hewan coba sampai ke tahap terminasi, sehingga kami hanya memproses organ yang akan diteliti. Berdasarkan intervensi diet yang telah dilakukan, sampel dibagi menjadi 3 kelompok, yaitu : Kelompok I diberi diet kurang kalori (dikurangi $30 \%$ dari diet standar), Kelompok II diberi diet standar (BPOM), kelompok III diberi diet tinggi lemak (mengandung 20\% lemak). Setelah hewan coba diterminasi, organ hati yang berlokasi di rongga abdomen segera dieksisi dengan hati-hati, kemudian ditimbang dalam kondisi segar. Penelitian ini menggunakan desain riset eksperimental, untuk menilai perbandingan berat hati antar kelompok. Analisis stasitstik dilakukan dengan menggunakan program SPSS 20.0.0 version for mac.

\section{HASIL PENELITIAN}

Pengukuran berat hati dilakukan untuk melihat apakah terdapat kenaikan jika dibandingkan dengan kelompok pakan 
standar. Pengukuran berat hati dilakukan pada minggu ke-8 setelah perlakuan. Hasilnya rerata berat hati pada kelompok TK lebih tinggi dibandingkan dengan kelompok KK dan CK (Gambar 1).

Berdasarkan uji normalitas berat hati dengan Saphiro-Wilk didapatkan data terdistribusi tidak normal dan homogen dengan $p<0,05$, sehingga dilakukan uji nonparametrik Kruskal-Wallis. Hasil uji statistik Kruskal-Wallis menunjukkan terdapat perbedaan bermakna antar kelompok dengan $p<0,05 \quad(p=0,002)$, selanjutnya untuk mengetahui kelompok mana yang memiliki perbedaan dilakukan uji post hoc dengan Mann-Witney (Lampiran 6). Hasil uji Mann-Witney menunjukkan terdapat perbedaan bermakna antara kelompok KK dan CK, KK dan TK, serta CK dan TK dengan $p<0,05$ $(p=0,008)$.

\section{PEMBAHASAN}

Secara klinis, perlemakan hati non alkohol (NAFLD) biasanya disertai dengan hepatomegali. Akumulasi lemak di hati dapat menyebabkan kenaikan berat hati $>20 \%$ dari berat hati normal. Pada NAFLD, hepatomegali tidak dapat dijadikan dasar diagnostik. Standar baku yang digunakan adalah pemeriksaan histopatologi. Pada penelitian ini, pemeriksaan berat hati dilakukan sesaat setelah tikus dikorbankan, yaitu dengan menimbang langsung berat organ hati segar. Hasilnya, terdapat perbedaan bermakna dengan rerata tertinggi pada kelompok TK (tinggi kalori). Pada kelompok TK terjadi kenaikan berat hati $\pm 20 \%$ dari kelompok CK (cukup kalori/pakan standar), sedangkan kelompok KK (kurang kalori) memiliki berat hati yang lebih rendah $\pm 40 \%$ dari kelompok CK. Studi oleh van Zutphen dkk (2016) menunjukkan tikus yang diberi pakan tinggi kalori-protein memiliki berat hati lebih tinggi dari kelompok kontrol, sedangkan kelompok yang diberi diet rendah protein selama 4 minggu, memiliki berat hati yang lebih rendah dari kelompok kontrol. ${ }^{14}$

\section{KESIMPULAN DAN SARAN}

Terdapat perbedaan berat hati antar kelompok perlakuan, dimana pemberian diet tinggi kalori dapat menyebabkan peningkatan berat hati. Sebaliknya, pemberian diet rendah kalori menunujukkan berat hati yang lebih rendah dari kelompok pakan standar.

\section{DAFTAR PUSTAKA}

1. Niwa H. Hasil Riskesda 2018. Jakarta: Kementrian Kesehatan RI; 2018;134(4):635-46p.

2. Müller O, Krawinkel M. Malnutrition And Health In Developing Countries. Can Med Assoc J. 2005;173(3):2000-3.

3. Maleta K. Undernutrition. 2006;18(December):189-205p.

4. Guyton L, Hall F, Training O, Training P, 
Darin C, Training RO, et al. Guyton and Hall Textbook of Medical Physiology. Igarss 2014. 2014. 1129 p.

5. Johnson, Bruce R. Ober, William C. Silverthrone AC. Human Physiology An Integrated Approach. 7th ed. 2013.

6. Gartner L, Hiatt J. Buku Ajar Histologi Berwarna. 3rd ed. Suryono I, Damayanti L, Wonodirekso S, editors. Indonesia; 2010. 408-418 p.

7. Fawcett DW. Buku Ajar Histologi. 12th ed. Hartanto H, editor. Jakarta; 1994. 583$605 \mathrm{p}$.

8. Wood EJ. Marks' basic medical biochemistry: A clinical approach (second edition) [Internet]. Vol. 34, Biochemistry and Molecular Biology Education. 2006. 395-395 p.

9. Takahashi Y, Fukusato T. Histopathology of nonalcoholic fatty liver disease / nonalcoholic steatohepatitis. World J Gastroenterol. 2014;20(42):15539-48.

10. Brunt EM, Tiniakos DG. Histopathology of nonalcoholic fatty liver disease. World J Gastroenterol. 2010;16(42):5286-96.

11. Cahyono, JB. Suharjo B. Hepatitis A. Yogyakarta: Kanisius; 2009.
12. Krisnansari D. Nutrisi dan Gizi Buruk. Mandala Heal. 2010;4((1)).

13. Keenan K. Diet, caloric restriction, and the rodent bioassay. Toxicol Sci. 1999;52(90001):24-34.

14. van Zutphen T, Ciapaite J, Bloks VW, Ackereley C, Gerding A, Jurdzinski A, et al. Malnutrition-associated liver steatosis and ATP depletion is caused by peroxisomal and mitochondrial dysfunction. J Hepatol. 2016;65(6):1198208.

15. Manaf A. Insulin Resistance as a Predictor of Worsening of GlucoseTolerance inType 2 Diabetes Mellitus. Medicinus. 2014;27(8):3-8.

16. Sianturi M. NON ALKOHOL TIKUS SPRAGUE DAWLEY ( The Effect of Trans Fatty acid on Non alcoholic Fatty Liver Disease in Sprague Dawley Rats ). 2012;1-17.

17. Asgharpour A, Cazanave SC, Pacana T, Seneshaw M, Vincent R, Banini BA, et al. A diet-induced animal model of nonalcoholic fatty liver disease and hepatocellular cancer. J Hepatol. 2016 Sep 1;65(3):579-88. 


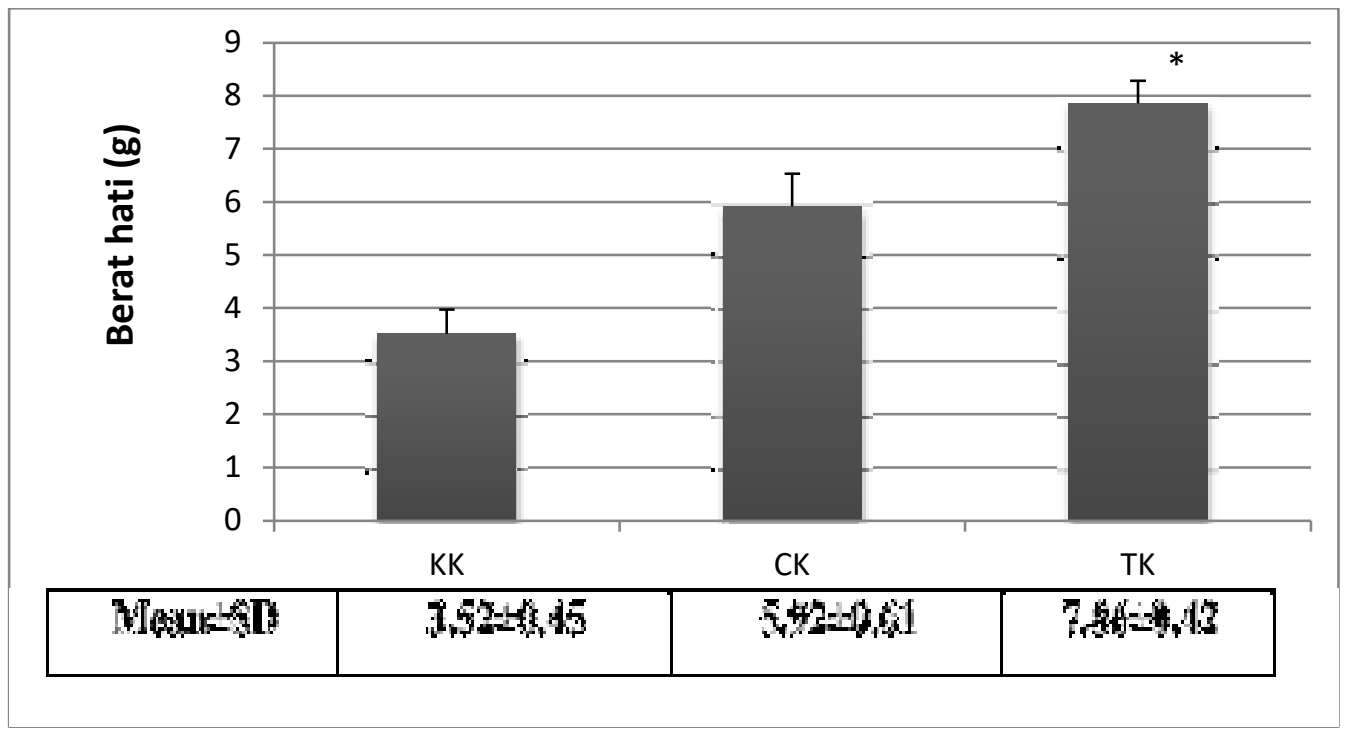

Gambar 1. Grafik batang berat hati tikus menunjukkan mean TK (tinggi kalori) lebih tinggi dibanding kelompok KK (kurang kalori) dan kelompok CK (cukup kalori/pakan standar) 